\title{
3 The materiality of meaning networks
}

I live in the world of others' words ${ }^{1}$

This chapter draws on one particular observation of the previous chapter. We saw how segmental speech components were sometimes combined with shifting referential structures. While in one recension a given speech component is associated with a certain speaker, in another recension that persona of antiquity may well be the speech's recipient, rather than the orator. This suggests that a modular principle to some extent informed the built-up of what we later come to see as Shū texts; it moreover indicates there were strong associate links between the speech component on the one hand, and a given persona of days yore on the other. Despite their modular character, the associative links they produce are therefore not random. The link between speech and persona remains intact - irrespective of the role they actually play.

Let me explain. There are plenty of examples where a hardened speech component (for convenience called ' $A$ ') relates to a persona of antiquity (called ' $X$ ') as either the orator $\left(X_{0}\right)$ in one recension, or as the recipient $\left(X_{R}\right)$ of that speech in another. However, I have not seen a single speech component (A) relating to a given persona $\left(\mathrm{X}_{\mathrm{O}}\right.$ or $\left.\mathrm{X}_{\mathrm{R}}\right)$ in one recension, but to someone else $\left(\mathrm{Y}_{\mathrm{O} / \mathrm{R}}\right)$ in another.

This phenomenon goes even further, pertaining to the use, and thus the production, of Shū more profoundly. To study the ways groups of individuals made use of Shū traditions therefore necessitates that we leave behind the canon-centred paradigm of imperial Shàngshū and Yì Zhoushū because implicitly it considers the layered texts as the primary level of meaning construction and signification. Because the latter claims consistency, projected from the imperial texts back to the textual condition of the Warring States, it obscures Warring States realities. Rather than thinking that the communities worked with Shū primarily by reduplicating model texts in different circumstances, communication using the genre of Shū was such that it allowed groups to deploy shared cultural capital by reproducing a repertoire of modular elements from it together with other, closely intimately linked, items. Over time associative links between certain elements of the Shū traditions then stabilised, producing structures suitable for groups to use when formulating their own arguments. In this way old cultural capital was

1 Bakhtin 1986: 143.

Ә Open Access. () 2021 Dirk Meyer/JAS, published by De Gruyter. (c))BY-NC-ND This work is licensed under the Creative Commons Attribution-NonCommercial-NoDerivatives 4.0 License.

https://doi.org/10.1515/9783110708530-004 
moved into new problem space, lending weight to sociopolitical and philosophical thinking in the present. By laying bare these structures, the analysis throws into sharper relief the deep structures of meaning production and argumentation in the Shū genre. I base my analysis on exemplary readings of Qīnghuá "Hòu Fù" 厚父.

\subsection{Genre}

In this book I differentiate the Shū genre from the Shū traditions. I take Shū genre as something performative, produced by reference to old cultural capital; the texts built up from this make the Shū traditions. Methodologically this differentiation between the social act of working with the Shū traditions on the one hand, and the actual concretisation of these traditions through the texts produced by the different groups on the other, crucially enables me to go beyond what sometimes appears as static ideas and their textual representation, and instead analyse in greater detail the social use of dynamic traditions and their contemporary adaptability. Moreover, it enables me to spell out more clearly the 'rules'-insofar as there are any-behind the appropriation of old cultural capital for the presentation of claims in the present in the Shū genre. I am thinking about the iterability of text.

Some considerations about genre by the Russian literary theorist Sergey Sergeevich Averintsev (1937-2004) are useful here. In his essay on the "Historical variability of the category of genre", written in the mid-1980s, Averintsev introduced the notion of performance as he attempted to define genre beyond its common indexicality. ${ }^{2}$ To him, the particular situation of an utterance, a speaker's gestures, as well as intonations, are all part of what defines a genre. He cites the example of the ritualised setting of a communal feast, where the moving of an object that was passed on from one participant to another, indicating who was expected to sing, was crucial. ${ }^{3} \mathrm{He}$ acknowledges that the material thickness of such a ritual experience is much lessened in the increasingly literarised performance of, say, the epic. Yet, as Averintsev suggests, and I follow him here, the genre determination of such literary actualisations 'cannot be restricted to the reality of literature itself' because 'the poetic rhythm of the Book of Parables and even the hexameters of the Iliad' do not yet constitute the self-sufficient literary

2 Averintsev 1986. I thank Yegor Grebnev, who brought my attention to this piece. I have consulted his unpublished translation of Averintsev's essay.

3 Ibid., 5. 
fact of 'metre'; rather they are 'a reflection of the fact that the biblical aphorisms existed in the ceremonial chanting of "the wise men", and the Homeric epic in the chanting of bards'. ${ }^{4}$ As Averintsev puts it, it was still 'literature-in-itself', not 'literature-for-itself', as it would not yet have developed its own self-consciousness that would 'look at its own self through the mirror of criticism and theory', thus 'consciously representing and constituting itself as literature'. He calls this 'pre-reflexive state' of literary activities 'pre-reflexive traditionalism'. ${ }^{5}$ With the developing of a reflexive state, which for the Greek side Averintsev sees completed in the fifth century $\mathrm{BC}$, the extra linguist situation no longer defines the genre; it is now replaced by literary norms. It has become 'literature-for-itself'.

There is a lot to say about Averintsev's progressive model and the sharp divide he introduces between 'reflexive' and 'non-reflexive' stages in literary production. But even if we do not force the teleological lens on the literary activities of the social communities in China, as Averintsev does for Greece; and even if we leave aside the issue of cognitive realisation with its strongly Hegelian complexion, there is still much value in Averintsev's perceptive analysis. Needless to say, 'pre-reflexive' and 'reflexive' modes, if we follow his terminology for the moment, can happily go together and need not replace each other. The ritualised wailing with the beating of one's breast; the moving of the cup in the utterance of a libation ritual, none of this needs come to an end when certain communities produce literary activities guided by their own premises. Moreover, this shift in literary production itself does not have to be made explicit by and to the participating communities - there is no need to assume it must necessarily be reflexive to take effect. But the act of literary performance that is guided by its own premises, be it reflexive or not, is an important insight and crucially informs my reading of the stabilising of the Shū genre during the Warring States period. It guides my understanding that the way communities move old cultural capital into new argument space through Shū was not random but governed by conventions, be they explicit or not.

In this my take on performance follows Richard Bauman's thesis of performance 'as a mode of communicative display'. ${ }^{6}$ An utterance is connected to a discursive practice through intertextual links. ${ }^{7}$ The sociohistorical reality produced

4 Ibid., 6.

5 Ibid., 7.

6 Bauman 2004: 9.

7 Genette 1997: 1 defines 'intertextuality' as 'the textual transcendence of the text', that is, its interactive alignment with other texts. This definition rings with Bakhtin's 1986: 162 discussion of 'text' as the ways in which 'each act of textual production presupposes antecedent texts and anticipates prospective ones’. (Bauman 2004: 4) 
by such interdiscursive affiliations thereby rests upon the activation of cultural capital-Bauman calls it 'cultural repertoire' ${ }^{8}$ - serving as conventionalised framework for the 'production, reception, and circulation of discourse'. ${ }^{9}$ In this way genre actively channels the production and reception of a particular kind of text by assimilating an utterance through its intertextual links with previous utterances. Certain framing devices are key in this. Linking an utterance to discourse, for Bauman, means in particular that a performer signals to the audience something to the effect of 'hey, look at me! I'm on!' I consider the mode of communicative display by moving cultural capital into new argument space as a strategy by which groups link their sociopolitical and philosophical concerns to a specific discourse. Either way, it means that the act of expression itself is 'framed as display' and so, following Bauman, it becomes 'objectified' in the eyes of their contemporary beholder. Applied to the material under review it follows that the articulation of a current sociopolitical and philosophical concern through the manner of Shū releases it from its 'contextual surroundings', which opens it up to 'evaluative scrutiny' by the audiences. ${ }^{10}$ My discussion of "Gù mìng” and “^Băo xùn” in the next chapter will develop this more fully. Here it suffices to say that framing and entextualisation are crucial - and crucially interlinked. ${ }^{11}$ The framing formula 'the king said thus' (wáng ruò yue 王若曰) may be cited here as one such marker of Shū-display. It creates an expectation that constitutes the 'framework for entextualisation', by which 'a stretch of discourse is organised into text'. ${ }^{12}$ Moving old cultural capital into new argument space to Bauman thus objectifies the utterance; linking a group's sociopolitical and philosophical concerns to a specific genre by modes of intertextuality thus objectifies the act of expression. The metacommunicative message achieved in this way signals accordingly 'I am part of this discourse'. Or in our case: 'take me as an expression of the Shū traditions!'

8 My use of cultural capital for Bauman's 'repertoire' is unproblematic as it simply points to the higher level of value. The repertoire is, in other words, the currency of the capital, its actual, modular, representation.

9 Bauman 2004: 2.

10 Foley 1991, 1995.

11 'Recontextualisation' is when signs, text, or meaning more broadly are taken from their previous contexts - this is commonly termed 'decontextualisation'-and placed in a new environment, referred to as 'entextualisation'.

12 Bauman 2004: 4. 
As the maturing of manuscript cultures during the Warring States led to unprecedented flows of information, ${ }^{13}$ different communities found access to this pool of material with increasing ease. As writing became ever more widespread and, as a result, further removed from central power, contrasting conceptual communities increasingly articulated their sociopolitical and philosophical concerns through texts that circulated ever more independently of their composers. ${ }^{14}$ The result is twofold. On the one hand we see a steadily more systematic approach to the past in these texts; ${ }^{15}$ on the other we notice an increase in the use and diffusion of the modular components of old cultural capital spread across the literature and entextualised in manifold ways.

Moving old cultural capital into new problem space by weaving a repertoire of it into constructed narratives allowed contrasting sub-groups of the wider meaning community of the Zhōu oecumene to articulate their concern with ancient backing. A discourse thus emerged where past glories were retrospectively systematised for a variety of claims in the present. Certain features now became an expected requirement for these texts, allowing different social groupings to take part in these debates, with the result that some features of the texts were repeated across different texts, thereby gaining a fixed character. This applies in particular to the framing formulae of these texts, but other elements also followed. With their archaic language, the marked use of direct speech put into the mouth of ancient personae, the repeated framing formulae in these texts, as well as certain themes increasingly required in them, it becomes plain that during the Warring States these texts drive the development of a genre: Shū became a type of argumentation which channelled subsequent forms of text production.

\section{2 "Hòu Fù"}

"Hòu Fù" is ideally suited to demonstrate how some of the associative links in Shū genre work. It is a relatively brief manuscript text commonly dated around $300 \mathrm{BC}$ and recorded in neither Shàngshū nor Yì Zhōushū. Now part of the Qīnghuá manuscripts, it presents a recorded conversation between a 'king' (wáng

13 Meyer 2011, 2014; Krijgsman 2016. For methodological reflections, see the work by Steve Farmer 2006; 1998. Farmer further developed his model in a series of co-written papers. See most importantly Farmer, Henderson and Robinson 2002; Farmer, Henderson and Witzel 2002; Farmer, Sproat and Witzel. 2004.

14 Meyer 2014.

15 Kern 2017a. 
王 ${ }^{16}$ and someone named 'Hòu Fù' 厚父 (Lord Hou). The name does not appear outside this text and we should not assume that the text presents an actual, historical, occurrence. Most likely it records an imagined conversation. The conversation itself provides nothing unexpected. It repeats the usual themes (not to say clichés) of recorded dialogue in texts of Shū traditions otherwise known from the Shàngshū and the Yì Zhōushū, as well as the Qīnghuá manuscript texts.

The reason why "Hòu Fù" receives special scholarly attention is in particular because it shows close intertextual correspondence with the received Mèngzǐ. In the Mèngzì the said phrase is clearly marked as Shū by the formula 'shū yue 書曰 ' (in a Shū it is said). ${ }^{17}$ However, while it features centrally in "Hòu Fù", it does not appear like this in transmitted records.

Scholars all too easily rushed to the conclusion that Qinghuá "Hòu Fù" is therefore a 'lost chapter of the Shàngshü..$^{18}$ The difficulty with this interpretation is that it makes unfounded claims about text consistency of both the Shàngshū and "Hòu Fù". It posits a stable canon prior to their historical curtailment and transposes the reality of imperial texts-Shàngshū and Yì Zhōushū-to the Warring States.

"Hòu Fù" is collected in vol. 5 of Qinghuá Manuscripts..$^{19}$ It is produced on thirteen slips. Unbroken slips are on average $44 \mathrm{~cm}$ long and c. $0.6 \mathrm{~cm}$ wide.

The first slip is broken at both ends. By my count circa four graphs are missing at the top; ten to eleven graphs are missing at the bottom. The remaining slips are all intact, allowing for an uninterrupted reading of the text. Because the slips are numbered at their back from 1-13, with number one missing because of the broken slip, the reconstruction of the slip sequence, and thus of the flow of the text, is unproblematic. The last slip also records the designation of the manuscript in question, or the fabula on which the text draws: "Hòu Fù". For convenience I render the text in full:

16 Here and elsewhere I render wáng 王 as 'king'. It is the sole pre-Qín title for which I use the English because it is relatively closely equivalent to European notions of 'king'. Due to conceptual differences, I leave other titles of the aristocratic ladder untranslated unless they acquired special significance, such as in 'Duke of Zhou' for Zhōu Gōng 周公. The order of the titles in the male aristrocracy is Gōng 公, Hóu 侯, Bó 伯, Zĩ 子, Nán 男.

17 Mèngzǐ “Liáng Huìwáng xià”: 215.

18 Qīnghuá Manuscripts vol. 5: 109.

19 For photographic reproductions of the slips, see Qīnghuá Manuscripts vol. 5: 2-4; 25-36; for transcription and notes, 109-116. 


\subsubsection{Frame}

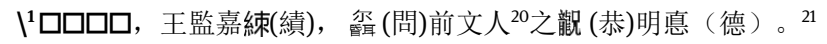

$l^{1} \square \square \square \square$. The king inspected the estimable merits and asked about the reverence and brilliant virtue of the cultured men of the past.

1.

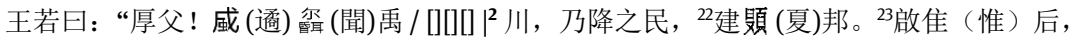
帝亦弗恐 (鞏)啟之經息（德），24少(乎)命处(臬)陶下為之卿事，茲咸又（有）神，能咯 (格)于上。25 3 智 (知) 天之畏 (威) 26 戈 (哉), 蛋 (聞)民之若否, 隹 (惟) 天乃永保顥

20 Cf. renditions of the phrase in Shàngshū “Wén Hóu zhī mìng” 追孝于前文人 'Your filial piety goes back to your accomplished ancestor'.

21 Cf. Shàngshū “Jūn shì” 不知天命不易, 天難諶, 乃其墜命, 弗克經歷。嗣前人, 恭明德 ‘I do not know whether the favour of Heaven is easily preserved; Heaven is difficult to depend on. Upon losing its favouring appointment one cannot pursue and carry out the reverence and brilliant virtue of one's forefathers'. As in "Hòu Fù", the phrase 'the reverence and brilliant virtue' relates to past accomplished men ('forefathers' 嗣前人 or 'cultivated men of the past' 前文人).

22 Cf. Shàngshū “Yī xùn” 惟上帝不常, 作善降之百祥, 作不善降之百殊 “(The ways) of the Dì on High are not invariable: to those who do good he sends down the manifold blessings; to those who do not-good he sends down the manifold miseries'.

23 Cf. Shàngshū “Yuè mìng” 建邦設都 ‘Founding states and setting up capitals’.

24 Cf. Shàngshū “Jiǔ gào” 經德秉哲 “Consistent in his virtue; holding fast his clarity.

25 Cf. Shàngshū “Yáo diăn” 欽、明、文、思、安安, 允恭克讓, 光被四表, 格于上下。克明俊 德 “He was reverential, intelligent, accomplished, thoughtful - with ease and no effort. He was sincerely respectful, and capable of yielding. Radiantly his bearing was felt through the four quarters (of the land), up to (Heaven) above and (Earth) beneath'; Shàngshū “Jūn shì” 在太戊時 則有若伊陟、臣扈，格于上帝 'At the time of Tàiwù there were people like Yì Zhì and Chén Hù, through whom [Tàiwù's virtue] reached up to the Dì on High'. Compare further with the following phrases from “Xián yǒu yī dé” where a number of shared aspects reappear 曰:「鳴呼！天難諶 , 命靡常。常厥德, 保厥位。厥德匪常, 九有以亡。夏王弗克庸德, 慢神虐民。皇天弗保。監 于萬方, 啟迪有命, 眷求一德, 俾作神主。惟尹躬暨湯, 咸有一德, 克享天心, 受天明命, 以 有九有之師, 爱革夏正 ‘[Yī Yĩn] said: Alas! it is difficult to rely on Heaven - its appointments are not constant. (But if the sovereign will see to it that) his virtue be constant, he will preserve his throne; should his virtue not be constant, the nine provinces will be lost thus. The king of Xià was not capable of maintaining the virtue (of his ancestors) unchanged, and he contemned the spirits and cruelly oppressed the mín. August Heaven would thus no longer protect him. Looking from above to the myriad quarters, it gave its lead to those who would receive its favouring command, fondly seeking (the possessor of) constant virtue so as to make him lord of the spirits. Then there were I, Yĩn, as well as Tāng, we both were of consistent virtue, capeable of recieving Heaven's mind'.

26 Cf. Shijining 272: (“Wǒ jiàng”) 我其夙夜、畏天之威、于時保之 ‘Do not I, night and day, Revere the majesty of Heaven. Thus to preserve [their favour]' (Legge, 576); Shàngshū “Duō fāng” 爾乃 惟逸惟頗, 大遠王命, 則惟爾多方探天之威, 我則致天之罰 'You, thereupon, will thus be shown as indolent and aberrant, and greatly disobedient to the royal commands. Then it is that 


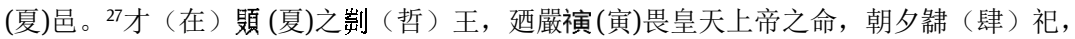

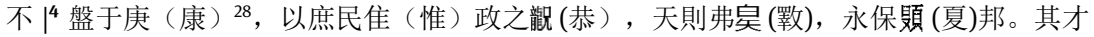
(在) 寺 (時) 後王之卿（享）或（國）, 禑（肆）祀三后, 永敘 (敘)在服 29 。隹（惟） 女（如）忽(台)?

The king said thus: 'Hòu! ${ }^{30}$ Obediently I have heard how the [Great] Yu /... $\left.\right|^{2}$ the streams; ${ }^{31}$ upon this, [he] established the domain of the Xià for the commonfolks (mín) descended [by Heaven]. When Qĩ was the sovereign, the Dì would surely refrain from obstructing (or consolidating?) the lasting powers of Qĩ; thence he ordered Gãoyáo below to take charge of the administrative affairs on his behalf. Thus they were all in possession of the spirits and able to make their [virtue] go up above. $\beta^{3}$ Understanding that Heaven's terrors are thus, and hearing whether the commonfolk were compliant or not, it is such that Heaven did ever thus preserve the settlement of the Xià. With the illuminated kings of the Xià thereupon respectfully heeding the commands of awesome August Heaven and High Dì, night and day bringing forth their offerings, and not $\left.\right|^{4}$ going excess in [their] pleasures, it is such that the various members of the commonfolks would respectfully receive their governance; ${ }^{32}$ Heaven ${ }^{33}$ would thence not grow weary [of them], ever preserving the domain of the Xià. From this on the kings following after him who would receive the lands would all carry on bringing forth offerings to honour the three lords, that ever their position be kept in proper sequence. How is this to us? (i.e., how does this relate to us?)

2.

厚 $\left.\right|^{5}$ 父拜-[手]稽=[首], 曰:

“者（都）魯! 天子! 古天降下民, 埶（設）萬邦, 作之君, 作之币（師）, 隹（惟）曰 其助上帝, 亂（亂）下民之匿（㗭） ${ }^{34}$ 。王廼渴（遏）| 6 失（佚）其命, 弗角（用）先折

throughout your numerous regions you will bring on yourselves the terrors of Heaven, and thus we will inflict on you the Heavenly punishments'.

27 Cf. Shàngshū “Zhōng huì zhī gào” 欽崇天道, 永保天命 “Revere and hold high the way prescribed by Heaven, and you will lastingly preserve the favouring appointment of Heaven'; “Zî cái” 欲至于萬年, 惟王子子孫孫永保民 'I wish that (your rule) may last for myriads of years; be it that the king's sons and grandsons forever protect the min'.

28 Cf. Shàngshū “Wǔzǐ zhī gē” 乃盤遊無度 “[He, however,] pursued his pleasurable wanderings without restraint'.

29 Cf. Shijing: 255 (蕩 “Dang”) 曾是在位、曾是在服 “That you should have them in offices; That you should have them in the conduct of affairs!' (Legge 1961: 506).

30 As it is used here, standing behind the name, fù 父 (甫) was the common part of a courtesy name ( $z i$ 字), not a kinship term, and thus somehow equivalent to our 'Sir'. It differs to its use in "Wén Hóu zhī mìng” and Máogōng-dǐng (Ch. 5) where it is placed in front of the name (父 X), thus marking the polite address to someone older than the speaker (i.e., the king).

31 About 10 graphs are missing at the end of the slip. The reconstruction of the phrase is therefore not possible.

32 This phrase is nearly identical in “Wú yì” of the Shàngshū: 文王不敢盤于游田, 以庶邦惟正 之供.

33 i.e., [The world under] Heaven.

34 Cf. Shàngshū “Tài shì shàng” 天佑下民, 作之君, 作之師, 惟其克相上帝, 寵綏四方。有罪 無罪, 予曷敢有越厥志? 'Heaven, for the help of the lower commonfolks, made for them lords, 
（哲）王孔甲之典刑, 真 (顛) 復 (覆) 氒 (厥) 惪 (德), 湳（沈）湎于非彝, 天廼 弗若, 廼述 (墜) 羊 (厥) 命, 亡氒 (厥) 邦。 7 住 (惟) 寺 (時) 下民, 倠 (洪) 帝之 子, 咸天之臣民, 廼弗慎羊 (厥) 㥁 (德), 角 (用) 敘才（在）服。”

Hòu $\left.\right|^{5}$ Fù obediently clasped his hands and, with his forehead touching the ground, and he said: 'Alas! Son of Heaven! In antiquity Heaven ${ }^{35}$ gave birth to (sent down) the commonfolks (mín) below and set up the myriad lands. It made them lords and armies that are said to assist the Dì on high to tame the wrongdoings of the commonfolks below. Thereupon the kings exhaustively $\left.\right|^{6}$ lost their command, for they would not use the statutes and laws of the former illustrious king, Kǒng Jiă, ${ }^{36}$ but subvert their charismatic power by sinking into the habits of unruly behaviour (i.e., drinking); Heaven, thereupon, would know no pardon, and it would let fall their Mandate, having them lose their lands. $\left.\right|^{7}$ At this the commonfolks below, as well as the offspring of the son of the magnanimous Dì, all being Heaven's chén and min, ${ }^{37}$ would thus no longer 'carefully guard their [king's] charismatic power', ${ }^{38}$ that they 'keep their position in proper sequence'.

3.

王曰: “欽之哉（哉）, 厚父！隹（惟）寺（時）余經 $\left.\right|^{8}$ 念乃高且（祖）, 克憲（憲）皇 天之政(征)工 (功), 迺虔秉羊 (厥) 惪 (德), 作辟事三后。影（肆）女（如）其若龜 筮之言, 亦勿可漙（專）改。茲 $\left.\right|^{9}$ 少（小）人之㥶（德）, 隹（惟）女（如）約(台)?”

The king said: 'be reverent, Lord Hou! It is such that I lastingly $\left.\right|^{8}$ ponder your great ancestors who were able to establish as a standard August Heaven's punitive achievements, that devoutly they held fast to their charismatic power. They set up the regal affairs of the three Lords. He committed you, [Lord Hou,] that just like the words of milfoil and turtle shells (i.e., divination speech) this must indeed not be changed singlehandedly! Such is also the charismatic power of me, the $\left.\right|^{9}$ small man. How does this relate to us?

4.

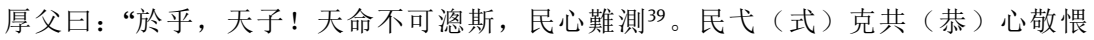
（畏），畏不恙 (祥)，保教明惪（德） ${ }^{40}, \mid 10$ 慎肆祀。

and made for them armies (this is generally read 'teachers'), that they be capable to serve the Dì on High, and secure the tranquillity of the four quarters (of the kingdom). Whether committed wrongful conduct or not, how would I dare to have the temerity to transgress your wishes?'

35 For a lack of such phrasing in the transmitted records an alternative would be to read gǔ 古 in gǔ tiān 古天 as gù (故/固) ‘verily’.

36 Interestingly, Kǒng Jiǎ does not otherwise appear in the Shàngshū or Shïjing. In the transmitted literature he only appears in texts from the Hàn dynasties onwards.

37 Thus: both groups were installed by Heaven as Heaven's chén and Heaven's mín.

38 The sentence repeatedly appears in bronzes. It is also seen similarly in Shàngshū "Wǔzì zhī gē” 五子之歌 (Songs of the Five Sons).

39 Cf. Shàngshū “Cài Zhòng zhī mìng” 民心無常 'The hearts of the mín have no constant attachment'.

40 Cf. Shijīng: 241 (“Huáng Yř”) 帝謂文王、予懷明德 “The Dì addressed King Wen, “I embrace [your] brilliant virtue”; Shàngshū “Shào gào” 保受王威命明德 “To maintain and receive his majesty's dread command and brilliant virtue'. 
住（惟）所役之司民啟之，民其亡諒，輏弗畏不恙（祥）。亡㬎（顯）于民； ${ }^{41}$ 亦隹（惟） 歌（禍）之占（做）及，住（惟）司民之所取。今民 $\left.\right|^{11}$ 莫不曰‘余保教明息（德） ${ }^{42}$ ，亦 鮮克以誨。43”

Hòu Fù said [to this]: 'Alas, Son of Heaven! Heaven's Mandate cannot be trusted, ah! The mind of the commonfolks is difficult to fathom. But the commonfolks ought to be able to respectfully use their heart-mind and reverently show awe, that they are fearful of the signs of misfortune, preserve the teachings and make bright their charismatic power, and $1{ }^{10}$ meticulously attend to set forth the sacrifices. Was it [such] that the commonfolks' overseer, forcing them into corvee labour, would enlighten them, the commonfolks clearly had no faith, upon which they would show no fear against what bates ill fortune. ${ }^{44}$ If this is not made manifest brightly in the commonfolks, then clearly it is indeed when misfortune strikes that the overseer of the commonfolks seizes [the opportunity]. But if among the commonfolks today $\left.\right|^{11}$ there is none who would not say: 'I shall preserve [their] teachings of the brilliant charismatic power', then indeed this is seldom achieved through instructions by way of mouth.

5.

曰: “民心隹 (惟) 桑, 羊 (厥) 作隹 (惟) 枼 (葉), 引(矧)其能丁 (貞) 良于苗, 人

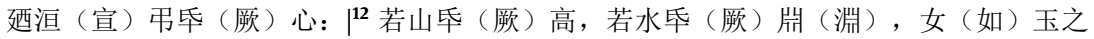
才（在）石，女（如）丹之才（在）朱一一迺是隹（惟）人。”

[He] said: 'The heart-mind of the commonfolks is like the trunk of a [mulberry] tree; their doings are like [mulberry] leaves; how much more (shěn) if they could become good fruits of a young seedling! Members of the rén group would thereupon greatly improve their heartminds: $\left.\right|^{12}$ just like mountains they [would be thus] tall; just like the waters they [would be thus] deep; [they would be] like jade in a stone; like the red of cinnabar - and so it is with the rén.

41 Cf. Shàngshū "Jiǔ gào": 罔顯于民祇 'So that no charges came from him brightly before the people'.

42 Cf. Shī: 予懷明德 'I cherish your brilliant virtue’; Shàngshū “Kàng gào: 克明德慎罰 'He was able to make bright his virtue and be careful in the use of punishments'; “Shào gào”: 保受王威 命明德 “to maintain and receive his king’s dread command and brilliant virtue’; 弗克經歷。嗣 前人, 恭明德 “Because they were not able to pursue and carry out their forefathers' reverence and brilliant virtue'; “Duō fang” 罔不明德慎罰 'Noone did not make bright their virtue and carefully use the punishments'; “Wén Hóu zhī mìng” 克慎明德 “Carefully did they make their brilliant virtue'

43 Cf. Shàngshū “Bì mìng” 鮮克由禮 ‘Few are capable to observe the rules of propriety’.

44 Other possibility: 'upon which they would show no fear against what bates ill fortune, that no charges could come brightly before the commonfolks.' 
6.

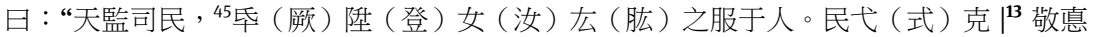
（德），母（冊）湛于酉（酒）。民日：“倠（惟）酉（酒）角（用）肆祀，亦隹（惟） 酉 (酒) 角 (用) 庚 (康) 樂。”

[He] said: 'As Heaven is inspecting the commonfolks, their ascending is like the upper arm in its service to a man. The commonfolks surely ought to be able to $\left.\right|^{13}$ show reverence to charismatic power, [thus] do not drown it in wine. The commonfolks will say: 'it is wine [they] use to carry out the si sacrifice; indeed it is wine [they] use to enjoy the pleasures'. 7 .

日：“酉（酒）非飤（食）, 隹（惟）神之卿（享）。民亦隹（惟）酉（酒）角（用）敗 畏 (威) 義 (儀), 亦隹 (惟) 酉 (酒) 角 (用) 恒 (興) 㾠 (狂)。”

[He] said: 'Wine is not for feasting, it is to give as offering to the spirits. Surely it is indeed the wine by which the commonfolks will lose their respect for dignified comportment, and surely it is indeed the wine by which they are roused into a craze.

\subsection{Meaning Networks in “Hòu Fù” and Shū Genre}

Much of what "Hòu Fù" produces resonates with themes and notions in other Shū texts, Qinghuá included. Concerns expressing that 'Heaven's terrors' are such that one cannot rely on Heaven's support; ideas about Heaven's sending down upon the rén and min a certain quality; ${ }^{46}$ the consolidation of the state; the working for the trust of the min; anxieties about the rén; tensions of alcohol and ritual - all this strikes even the casual reader of the Shàngshū as familiar. But not just the themes of the text are well known. The entire build-up of "Hòu Fù" reads like a smörgåsbord of common Shū phrases. This includes its reference to 'accomplished ancestors' (前文人); 'reverence and brilliant virtue' (恭明德); the ability to make one's virtue 'go up above' (能格于上) to 'ever preserve' (永保) the royal domain; 'wise kings' (哲王) of the past; for the sovereign to 'carefully guard their charismatic virtue' (慎厥德) that they 'keep their position in proper sequence' (用 敘在服); Heaven's inspecting the commonfolks (天監司民); the 'mind of the commonfolks' (民心) which is 'difficult to fathom' (難測) $)^{47}-$ to name just a few items of the text chosen at a random.

45 Cf. Shàngshū “Gāozōng róngrì”: 曰: 惟天監下民, 典厥義 “[He] said: in its inspection of the commonfolks below, Heaven first considers their rightness'.

46 In Qīnghuá "Mìng xùn” a generic mìng 'command' is making rén and mín descend.

47 Or, as put in Shàngshū “Cai Zhòng zhī mìng”: 民心無常 “The commonfolks' hearts have no unchanging attachment, (they cherish only the kind)'. 
As is typical of texts of the Shū traditions, "Hòu Fù" offers only minimal context information. The little it says is given in the first few sentences, framing subsequent speech. In this case the speech is produced as a dialogue between two actors, an unnamed 'king' and the otherwise unknown character Lord Hou.

The dialogue is organised in seven units, each of which headed by an explicit marker of speech - a common feature of Shū texts. There is no action other than the speeches, except the to-the-point-mention of the king's enquiry in the text's frame, as well as the brief description of Lord Hou's ritual gesture of obedience, which heads his exclamation in unit two in response to the king.

Asking about the deportment of their forefathers, the king of "Hòu Fù" seeks to establish an agenda for securing his own rule through the work of ministers and advisors, in particular the assistance of Hou. His conviction is that Heaven can be 'read' and, by properly observing the ritual performance of the due sacrifices, the commonfolks ( $m i n$ ) will be kept in check.

Lord Hou then complicates the king's picture of how the king may secure his rule in the long run by insinuating that the Heavenly Mandate 'cannot be trusted' and the 'mind of the commonfolks is 'difficult to fathom'. For this reason governance must install a framework that allows the commonfolks ( $m i n$ ) to be in awe of the workings of the state and, by extension, the working of the world around them. Hence the king must seek to understand the mind of the commonfolks, because their actions are all dependent on this. The mind of the commonfolks, for its part, rests on the actions of the ruler and their proper comportment. Should they indulge in drink, a common concern expressed in the Shū traditions, instead of using the wine in their offerings of sacrifices, they are sure to lose the respect, and thus the support, of these folks. In other words, the producers of "Hòu Fù" propound the idea of rule by moral force. This is a common notion in Warring States sociopolitical philosophy.

So far thinking of "Hòu Fù”. Unfortunately with slip one broken, the first four or so graphs of the text are irreversibly missing. We will therefore never know for sure which formula framed "Hòu Fù" and whether it was a formula typically seen in Shū texts. However, since common Shū patterns occur across the text it is clear that the communities behind "Hòu Fù" articulated their argument in a particular way so as to couch their message as part of the Shu traditions. Thus connecting their concern to a relevant discourse, it is reasonably safe to assume that some form of common Shū contextualisation also occurred at the text's beginning, had it been complete. Such framing patterns are often the event-immanent framing device 王若曰 'the king said thus'; or a time-place contextualising formula of the kind 惟 X 月/ 年 'it was in month/year X', or 惟 X 月 Y 'in month X, Y'; or 惟 X 有 
$\mathrm{Y}$ 年 'it was in the XY year..' (e.g., 惟十有一年) etc. Given that the phrase continues with the king taking notice of merits (王監劼績) we can safely exclude the former. Moreover, the event-immanent formula wáng ruò yue also occurs later on in the text when normally this formula appears just once. ${ }^{48}$ With roughly four graphs missing, the latter formula fits the space well.

Moving on from the initial frame, "Hòu Fù" repeats commonplace clichés of the Shu traditions, of which some produce webs of reference structures. To give an example, related to the initial notion of the king 'inspecting the estimable merits' in "Hòu Fù"-a phrase that in this form does not appear in the Shàngshū or the Yì Zhōushū but that resonates everywhere in Shù traditions, including the received texts-is the following structure: ' $\mathrm{X}$ ' (mostly Heaven in the Shū traditions but in this instance it is the king) is inspecting ' $Y$ ' (like in "Hòu Fù" this is generally something positive, such as merits or virtue), which are related to groups ' $Z$ '. This is common use in the Shū genre. In the Shū traditions these groups (' $Z$ ') are often comprised of the lower commonfolks ( $m i n$ ) but in this case they are the exemplary personae of the past. This deviation from the norm is, however, not too extraordinary, going to show the extent to which groups had autonomy in stretching common practice without breaking normative conceptual links in Shū genre.

"Hòu Fù" then continues by dropping the modular phrase 'reverence and brilliant virtue' (恭明德). In the Shū traditions the phrase occurs generally in the context of two central concerns: the unpredictable nature of Heaven's favours and the fears of losing them, generally paired with deliberations about continuing the deeds of their ancestors. This is also the reference structure adopted in "Hòu Fù", where the said modular phrase relates to the accomplished men of the past in exactly this manner. ${ }^{49}$

Then, having just dwelled on the 'lasting powers' (jīng dé 經德) of Qĩ-jīng dé is a widespread term that is, however, used variably in Shū genre as either denoting the 'lasting dé of X' or as 'taking as guideline the dé of X'-"Hòu Fù" reflects on the predecessors' abilities to make their virtue 'go up on high' (格于上). Just like in "Hòu Fù", this phrase often comes together with associative links pertaining to 'constant powers' (常德), 50 'preserving the throne' (保位), 51 'overseeing' the

48 More on this in Ch. 6: 187n.9.

49 Note that what in "Hòu Fù" and other Shū texts (as well as bronze texts from mid-Western Zhōu onwards) are the 'cultivated men of the past' (前文人) are sometimes also rendered as 'forefathers' (嗣前人). However, because of their shared reference structure they seem to be part of a common pattern of meaning construction.

50 Cf. jīng dé 經德 in “Hòu Fù”.

51 Cf. yǒng băo Xià yì 永保夏邑 “forever preserving the domain of the Xià' in “Hòu Fù”. 
multitude regions' (監于萬方), as well as the common possession (咸有) of either the 'spirits' (神) or, as in the received “Jūn Shì" of the Shàngshū, a 'common dé', where the associative links also occur in the context of bemoaning how difficult it is to 'rely on Heaven' as its 'appointments are not constant'.

If the above named examples were isolated instances of structural overlap between "Hòu Fù" and other texts of the Shū traditions we should probably not overrate them. But that is not so. Rather, it seems "Hòu Fù" is largely built up of modular phrases that appear throughout the Shū traditions, where they dwell on related topoi or themes, activating a shared referential web of signification in Shu genre.

Just like most of what we see in "Hòu Fù", section two is awash with common phrases and images of the Shū traditions. I shall look at one such phrase in particular, as it presents an interesting case of how structures of signification were redeployed, creatively, in Shū genre. With that I close my discussion of meaning networks.

Just as Lord Hou obediently touched his forehead to the ground, the text has him produce the following phrase:

\footnotetext{
古天降下民, 垁（設）萬邦, 作之君, 作之币（師）, 隹（惟）曰其助上帝, 亂（亂） 下民之匿（愿）

In antiquity Heaven sent down (i.e., gave birth to) the lower commonfolks and set up the myriad lands. It gave them lords and armies that they assist the Dì on high to correct the wrongdoings of the lower commonfolks.
}

This is the said phrase prompting scholars to speak of a lost chapter of the Shàngshü' - a conceptualisation of past activities that is problematic on so many levels. Not only does it seek to explain ancient textuality in reference to an imperial text-miscellany-one that to some extent was chosen at random-Shàngshü; it also tries to understand the polymorphic social realities of meaning construction during the Warring States through the model of static texts. It is useful to bring to our attention Bakhtin's assertion about intertextuality. Bakhtin insists that behind the interaction of texts is always 'a contact of personalities and not of things' ${ }^{52}$ Texts, in other words, are only the secondary products of the multifacetted social realities of meaning construction. The primary actors are peopleindividual or groups-participating in a discourse by way of entextualising old cultural capital into contemporary argument space.

The relevant passage of the Mèngž which triggered the debate reads as follows:

52 Bakhtin 1986: 162. 
書曰: 天降下民, 作之君, 作之師。惟曰其助上帝, 寵之四方。有罪無罪, 惟我在, 天 下曷敢有越厥志? In a Shū it is said: 'Heaven gave birth to (sent down) the lower commonfolks; it gave them lords and armies that they assist the Dì on high to pacify the four quarters [of the realm]. Whether they have fault or not, with us being here, how would anyone in the world have the temerity daring to transgress its wishes?' 53

The overlap of the two texts is indeed remarkable. Except the stress on antiquity, which is missing in the Mèngzi-as is the phrase '[Heaven] set up the myriad lands', which comes next-the two share four near-identical textual elements in reference to assisting the Dì on high that he may either 'tame the wrongdoing of the lower folks' in 'Hòu Fù", or 'pacify the four quarters [of the realm]' in the Mèngzǐ. Then they each drift off into different deliberations with no shared reference structures between them. The Shū as cited in the Mèngzì continues with three further phrases not seen in "Hòu Fù". It is clear that the Shū as cited in the Mèngž is not simply an abbreviated version of "Hòu Fù". Rather, "Hòu Fù" and the cited Shū of the Mèngzi each contain a shared set of phrases, which they use to contextualise a different matter.

The phrase 'Heaven sends down X' appears variously in Shàngshū and the Qinghuá manuscripts. But its use is not stable. Central to it is the verb 'sending down'. But even though it often appears in conjunction with the pair 'Heaven' and 'the commonfolks', the reference structure behind these phrases is not necessarily the same. Implied objects may produce very different webs of signification, even when the sentence structure remains intact.

The above-cited sentences show an interesting case of overlap with the oldscript “Tài shì" 泰誓 (Great Harangue)..$^{54}$ "Tài shì” is traditionally attributed to Zhōu Wǔwáng, addressing the nobility of the Zhōu just before attacking the Shāng. ${ }^{55}$ It reads as follows:

天佑下民, 作之君, 作之師, 惟其克相上帝, 寵綏四方。有罪無罪, 予曷敢有越厥志?

Heaven assisted the commonfolks below. It made for them rulers, it made for them armies, that they be able to aid the Dì on High to secure the tranquillity of the four regions. Whether they have fault or not, how dare I transgress its (Heaven's) wishes?

53 Mèngzǐ "Liáng Huì Wáng xiâ": 10.

54 Although “Tài shì” appears in part in the Shǐji traditionally ascribed to Sīmǎ Qián 司馬遷 (c. 145-c. 85 BC) and is repetedly referred to in texts of the Warring States, the fact that it is not part of the modern-script recension of the Shàngshū means the text ought to be treated with caution. There are possibly six different versions of it from different periods. See the discussion in Jiăng Shànguó 1988: 213-225.

55 For a study of textual overlap between the various "Harangues" in the Shàngshū, see Kern 2017a. 
The "Tài shì" is here near-identical with the Shū as cited in the Mèngzi. But even in this case we find they are used to express a different concern. The Shū of the Mèngž puts stress on the authority of Heaven as embodied in the awe-inspiring ruler, King Wen. In his presence, no one would ever dare to go against Heaven's will as articulated through him, the king. In "Tài shì", the phrase is put in the mouth of Fā, rhetorically the future King $\mathrm{Wu}$, and used to state that he dare not disregard the wishes of Heaven.

When comparing "Tài shì" with "Hòu Fù” more fully-it is not possible to do the same with the phrase as appearing in the Mèngzi because of its isolated use there-we find that the wider context structure of this line could hardly be more different from what is happening in "Hòu Fù". In the latter, Lord Hou invokes cultural memory to admonish his lord, the unnamed king, that he may not rely on Heavenly Command if he does not also fulfil his kingly duties in observing the statutes and laws of the former illustrious king. In "Tài shì", cited above, however, King Wu delivers an oration to the nobles of the Zhōu just before their battle with the Shāng. It stresses the rightful nature of their campaign, which is bound to be successful because, unlike the many officers of the Shāng, the Zhōu and their allies are of 'one mind' (惟一心).

Despite the obvious differences in the wider context structures of signification underlying the two speeches, one by Fā, the other by Lord Hou (and, as conceptualised yet again differently in the Mèngž̆, King Wen), the internal reference structure of the web of signification created by the modular speech items by and large remains intact, albeit certain components differ. On a macro level, in both orations the modular speech items appear within a web of references that point to regime change in the face of rulers indulging in drink instead of considering the wellbeing of their subjects. On the microscopic level, we see that five modular items remain in close interaction with one another in a relatively stable manner. The first of these is Heaven and its relation to the lower commonfolks. In one text ("Tài shì") Heaven aides the commonfolks; in the other ("Hòu Fù") it brings them forth. "Hòu Fù" further adds that Heaven also sets up the myriad lands, an item not considered in "Tài shì". The modular link of Heaven-commonfolks connects to three further-stable-items in both speeches. One, it made for them rulers (作 之君); two, it made for them armies (作之師); ${ }^{56}$ three, the thus-generated ability that the commonfolks (mín) assist the 'Dì on High': 'that they be able to aid the Dì on High' (惟其克相上帝) in “Tài shì” and ‘that are said to assist the Dì on High' ( 惟曰其助上帝) in “Hòu Fù”. These items connect to a reference structure that,

56 Tradition often renders shī 師 as 'models'. However, given the text's sense of Realpolitik I consider 'armies' more apt. 
contextually, stays intact in both orations: in one text it is to 'secure the tranquillity of the four regions' (寵綏四方); ${ }^{57}$ in the other it is 'to tame the wrongdoing of the lower commonfolks' (亂下民之痴). ${ }^{58}$

The above examples all point to the same phenomenon: the profound modular build-up of these texts. Their shared reference structures is evidence of a second- or third-order composition process that goes beyond the modular combination of discrete textual units to support a particular argument. This confirms that speaking of a 'lost Shàngshū chapter' because there are-admittedly close-intertextual correspondences between a passage in the Mèngž highlighted as 'Shū' on the one hand, and a manuscript text of the Qinghuá corpus on the other is, methodologically, ill-conceived.

\subsection{Conclusion}

The above observations do not present a one-off scenario. The list of examples showing modular reference structures in "Hòu Fù" could be continued if subjecting the entire text to fully-fledged systematic scrutiny. But "Hòu Fù" is not unique in this respect either. Other manuscript texts-and the same is equally true of the received texts as recorded in the Shàngshū and Yì Zhōushü-are also awash with referential webs of signification. They are made up of modular phrases that resonate with given sets of sociopolitical or philosophical topoi or themes, thus producing micro-networks of signification used variably in these texts.

The repertoire of modular speech components constituted a primary layer of Shū genre, which developed during the second half of the first millennium BC when manuscript cultures were maturing. This developing genre, fostered by the flow of information that came with the wealth of physically available texts in wider circulation, informed the communities debating at the time. These groups now came to exploit and reconceptualise old cultural capital to fashion new texts so as to advance their own sociopolitical and philosophical ideas by investing them with an ancient pedigree.

It is interesting that in Shū genre even though many of the common modular phrases remain within their larger referential structure, their applied meaning may differ substantially from one case to another. As well as to larger structures of signification, this also applies to the micro-level of the text, down to the individual sentence. The example of one such case of a larger meaning network is

57 "Tài shì".

58 "Hòu Fù". I discuss the complexities of the verb luàn 亂 in Ch. 4. 
telling. The use of excessive drink appears stably in the context of regime change and the lords' disrespect for the wellbeing of the commonfolks. However, in one instance the lord is admonished that because the Heavenly Mandate is unpredictable he must observe the statutes and laws of the former illustrious king so as to guard the 'mind of the commonfolks' (民心); in another, while redeploying the same web of correspondences, it is used in the context of a pre-battle speech delivered by the king to remind his allies that victory is inevitable because, unlike their enemy, the allies of the king are of one mind (惟一心). While the basic reference structure remains intact in the two texts, it is applied to entirely different settings.

On the micro-level of signification, we see many examples of modular phrases that are stable in their choice of words but differ in their wider meaning contexts. Take for instance the example of the common sentence in Shū genre that structures 'heaven' tiān 天 and the '(lower) commonfolks' xià mín 下民 around the central verb 'to send down' jiàng 降. In some cases (e.g., "Hòu Fù”) the use of the verb is transitive, thus giving us: 'Heaven sends down the lower min'; ${ }^{59}$ others (e.g., "Tài shì”) take an implied object: 'Heaven sends down (a quality) $\mathrm{X}$ for the lower mín'. What we see from this is exactly the same situation as above only that here it applies to the micro-level of signification: a relatively fixed (sentence) structure is redeployed in different settings where it attains altered meaning in line with what the text puts forward.

Examples of this kind abound. They go to show very clearly how the groups at the time worked with what was simply a mine of materials. Stable elements of the cultural capital are redeployed in different contexts by entextualising them flexibly in the space of a new argument, such that they serve their users' ends.

The above yields further implications. One is that to some extent we ought to reconsider the clear divide of old- and modern-script recensions in our evaluation of the social reality behind the Shàngshū. Of course, this should not suggest that the old-script texts of the Shàngshū are the products of the Warring States. That is out of the question. But the way in which communities brought these texts to light is structurally not so different from what happened during the Warring States. Even though the provenance of the old-script recension of the Shàngshū is uncertain, and its texts generally ought to be treated with great caution, it is nonetheless too easy to dismiss them a priori as 'forgeries'. It is the same attitude that considers what was a polymorphic reality of past activities of constructing meaning through the canon-centred paradigm of imperial text making, which

59 The Qīnghuá manuscript text “^Mìng xùn” which I discuss also below is another case in point. 
sets aside the texts of the old-script recension because of fixed, reductivist assumptions which chronically simplify what was, in fact, an exceedingly complex transmission history.

Reference patterns in texts of the Warring States suggest that the material of what is now titled "Tài shì" was used widely in the construction of argument at the time. The Mèngž̌ is just one example. Other include the Mòž̌ 墨子, Guóyŭ 國 語, Guănž 管子, and Zuǒ zhuàn. ${ }^{60}$

Nonetheless, there can be no doubt that "Tài shì" was repeatedly reconstituted, in different form across the centuries, perhaps millennia. ${ }^{61}$ As such it is clearly not the product of the Warring States. But do we really believe that the texts of the modern-script recension of the Shàngshū reflect anything remotely like their 'original' state? Hardly. In one way or another they were all reconstituted, variously, time and again - no matter whether modern-or old-script recensions. As Michael Nylan suggests, the old-script texts bear 'deuterocanonical' knowledge, 'spliced' with more recent materials, maybe even building on older archives. That is not so different from what was happening during the Warring States - except, of course, that 'archive' takes an entirely different meaning there; when thinking about Warring States activities, 'genre' performs this function.

The stabilising of Shū genre is therefore not equivalent to claims of text stability within this genre. Quite the opposite: certain text moulds are solidifying as they are now appearing repeatedly in texts of Shū description; ${ }^{62}$ given motifs are being used over and over; common fabulae are being repeatedly exploited; ${ }^{63}$ known memes reoccur time and again in various texts. ${ }^{64}$ However, whether there can be said to be fixed 'Shū texts' is yet a different matter. As I discuss below, during the Warring States ever more complex texts increasingly made for a good read. Even text titles occur. ${ }^{65}$ But to postulate a 'lost Shū text' just because a given phrase occurs in the transmitted records (in this case Mèngzi) while there is no counterpart of that phrase in the imperial miscellanies Shàngshū and Yì Zhōushū falls short analytically.

Shū genre actively channels the production and reception of a particular kind of text by assimilating an utterance-oral, written, or both-through links with

60 Chan and Ho 2003: 160-169.

61 As mentioned, Jiăng Shànguó 1988: 213-225 counts as many as six versions across the ages.

62 See the discussion in Ch. 4.

63 See the discussion in Ch. 5.

64 A very good discussion of memes is found in Gleick 2011: 310-323. See also Distin 2005.

65 See the discussion in Ch. 6. 
previous utterances. Intertextuality is central to this. By moving old cultural capital into a new argument space and framing it as an expression of Shū, an expectation is created that produces the 'framework for entextualisation'. Such a framework thus enables organising a stretch of discourse into text. In this way the new argument enters into debate. An argument produced in this way is therefore a performance activity that rearticulates cultural knowledge for present ends. Whether that is done in primarily written form - this may perhaps be the model for the texts of the old-script recension in their claim of political influence; or whether this happens in a combination of both in spoken and written delivery-I consider this a likely scenario of the articulation of Shu during the Warring States as reflected from the Qinghuá manuscirpts-is, I believe, secondary. By looking at the Shū traditions as representatives of a genre it is possible to draw a more accurate picture of how the conceptual communities engaged in and with this discourse without thinking via the contrastive poles of orality and literacy which are assumed as mutually exclusive practices by which meaning may be generated.

To approach the social reality behind the Shū traditions by reference to genre theory frees us from conceptualising Warring States-polymorphic trends in argumentation and meaning construction through the sole prism of texts where changes must reflect deviations of the norm. Instead the idea of Shū genre enables us to come up with a model to conceptualise dynamic Shū traditions, as we see them through the Qinghuá manuscripts, as a way in which people-groups or individuals-are integrating stretches of discourse in their making of an argument. Shū are a social phenomenon. The Shū traditions are the result of what people do. Shū genre is a way by which different conceptual communities can (re-)negotiate spaces of influence, be they practically oriented (for instance, meant to persuade someone at court about ways of ruling) or philosophical, say, in developing a programmatic vision of rule. They reflect not the interaction of things but people and their arguments. 